\title{
Hyperammina micaceus sp. nov.: a new foraminiferan species (Protista) from the Porcupine Abyssal Plain, northeast Atlantic
}

\author{
ANDREW J. GOODAY \& M. GABRIELLA MALZONE \\ Southampton Oceanography Centre, Empress Dock, European Way, Southampton SO14 3ZH, UK (e-mail:ang@soc.soton.ac.uk).
}

\begin{abstract}
The paper describes Hyperammina micaceus sp. nov., a distinctive new deep-water agglutinated foraminiferan from the Porcupine Abyssal Plain (PAP), northeast Atlantic (4850 m water depth). The new species is tiny ( $<1 \mathrm{~mm}$ long and 20-30 $\mu \mathrm{m}$ wide), with an oval proloculus which merges smoothly into the long, tubular part of the test. The test wall is composed of a single layer of plate-like mineral grains. Hyperammina micaceus occurs in most of the PAP cores collected between 1989 and 2002 and represents up to $4 \%$ (in one sample 18\%) of the live foraminiferal assemblage in the $0-1 \mathrm{~cm}$ layer ( $>63 \mu \mathrm{m}$ size fraction). It tends to be more common in samples collected during the late spring and summer (May to September), prior to the spring bloom, than in samples obtained during the autumn (October) and the earlier part of the year (March, April), before the spring bloom. Live specimens are concentrated in the $0-0.5 \mathrm{~cm}$ sediment layer but are uncommon in the overlying phytodetrital deposits and virtually absent below $1 \mathrm{~cm}$ depth. J. Micropalaeontol. 23(2): 171-179, November 2004.
\end{abstract}

\section{INTRODUCTION}

Morphologically simple agglutinated foraminifera are major constituents of deep-sea sediment communities (Snider et al., 1984; Gooday, 1990). One important genus, Hyperammina, has been known from deep-water environments for well over a century (Brady, 1878). Members of this taxon have an elongate test in which the bulb-like proloculus is followed by a long, tubular section. In recent diagnoses, these components are regarded as two distinct chambers (Loeblich \& Tappan, 1987; Sen Gupta, 1999). Most species of this genus are fairly robust and measure millimetres or even centimetres in length. Also present in deep-sea samples are a variety of much smaller $(<1 \mathrm{~mm})$ and very delicate Hyperammina-like species, most of which are undescribed.

The purpose of this paper is to describe one such species, first noticed by the senior author in samples collected in the abyssal NE Atlantic (BIOTRANS site) in 1986 (Gooday, 1988). The present description is based on material obtained at a nearby site on the Porcupine Abyssal Plain (PAP) (4850 m water depth). Faunal studies conducted here over a period of more than a decade (Gooday, 1996; Gooday et al., 1998; Gooday \& Rathburn, 1999) have revealed the presence of numerous undescribed foraminiferal species, most of them simple, monothalamous (single-chambered) types. Specimens of the new species suitable for molecular analyses are not yet available and so this description is based on traditional morphological characters.

\section{MATERIAL AND METHODS}

\section{The study area}

The PAP BENGAL site is located in the Porcupine Abyssal Plain, about $270 \mathrm{~km}$ southwest of Ireland (Fig. 1). The general characteristics of the site are described by Rice et al. (1994), Billett et al. (2001) and Levin \& Gooday (2003). The area is characterized by surface productivity values approaching $60 \mathrm{gC} \mathrm{m}^{-2} \mathrm{a}^{-1}$ and is overlain by Northeast Atlantic Deep Water (NADW) which originates in the Labrador Sea. The winter mixing layer above the PAP is approximately $500 \mathrm{~m}$ deep, leading to a sudden and substantial input of phytodetritus following the late spring/early summer phytoplankton bloom. These inputs are well documented by time-lapse bottom photography and sediment coring (Billett et al., 1983; Rice et al., 1986; Bett et al. 2001). The presence of phytodetritus on the sea floor has a major impact on all size classes of the benthic fauna (Gooday, 2002). The metazoan fauna of the BENGAL site has been documented in a number of studies (Thurston et al., 1994; Rice et al., 1994; Billett et al., 2001).

\section{Shipboard procedures}

Samples for foraminiferal analyses were collected using a multiple corer, a device that recovers simultaneously up to 12 cores with the sediment-water interface virtually undisturbed (Barnett et al., 1984). Station data are summarized in Table 1. The samples were collected during the period 1989-2002 as part of a long time-series study. As soon as possible after recovery, the cores were brought to a constant-temperature laboratory set close to the ambient deep-sea temperature $\left(c .3{ }^{\circ} \mathrm{C}\right)$. Phytodetritus aggregates were removed from the surface of each core using a Pasteur pipette or a pair of flexible forceps. The sediment was then sliced into $0.5 \mathrm{~cm}$ or $1 \mathrm{~cm}$ layers down to $2 \mathrm{~cm}$ depth, followed by $1 \mathrm{~cm}$ layers down to $5 \mathrm{~cm}$ or $15 \mathrm{~cm}$. All layers were preserved separately in $10 \%$ formalin buffered with sodium borate. In most cases, only the upper $1 \mathrm{~cm}$ layer and the superficial phytodetritus deposit were examined, although deeper layers were examined in a few samples.

\section{Laboratory procedures}

In the laboratory, the volume of each sediment layer (phytodetritus if present, $0-0.5 \mathrm{~cm}$ plus $0.5-1 \mathrm{~cm}$ or $0-1 \mathrm{~cm}$ ) was determined separately by allowing it to settle in a measuring cylinder for several days. In the case of earlier samples (Table 1), the entire upper one centimetre layer was analysed. Later samples, however, were split into sub-samples using a wet sampler splitter constructed following the design of Jensen (1982). Two of the resulting eight sub-samples were analysed. The samples or sub-samples were washed with tap water through a series of sieves (mesh sizes $150 \mu \mathrm{m}, 125 \mu \mathrm{m}$ and $63 \mu \mathrm{m}$ ) 


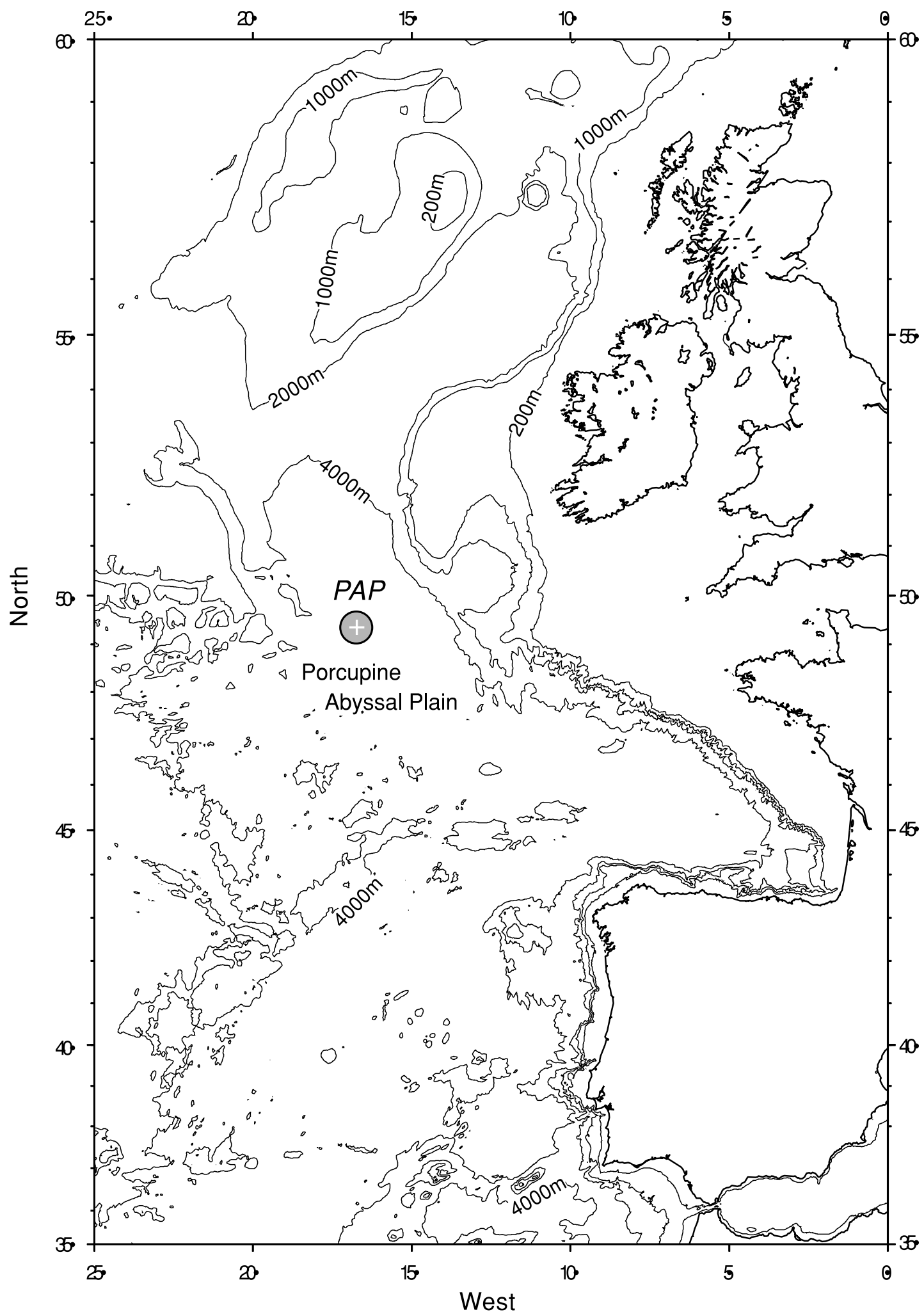

Fig. 1. Location of the study site on the Porcupine Abyssal Plain.

and stained in Rose Bengal solution on the sieves overnight. The stained fractions were placed in a Petri dish and sorted under a binocular microscope for all 'live' foraminifera.
Morphological study

Specimens of the new species were preserved on cavity slides in anhydrous glycerine for morphological studies. The maximum 
Hyperammina micaceus sp. nov.

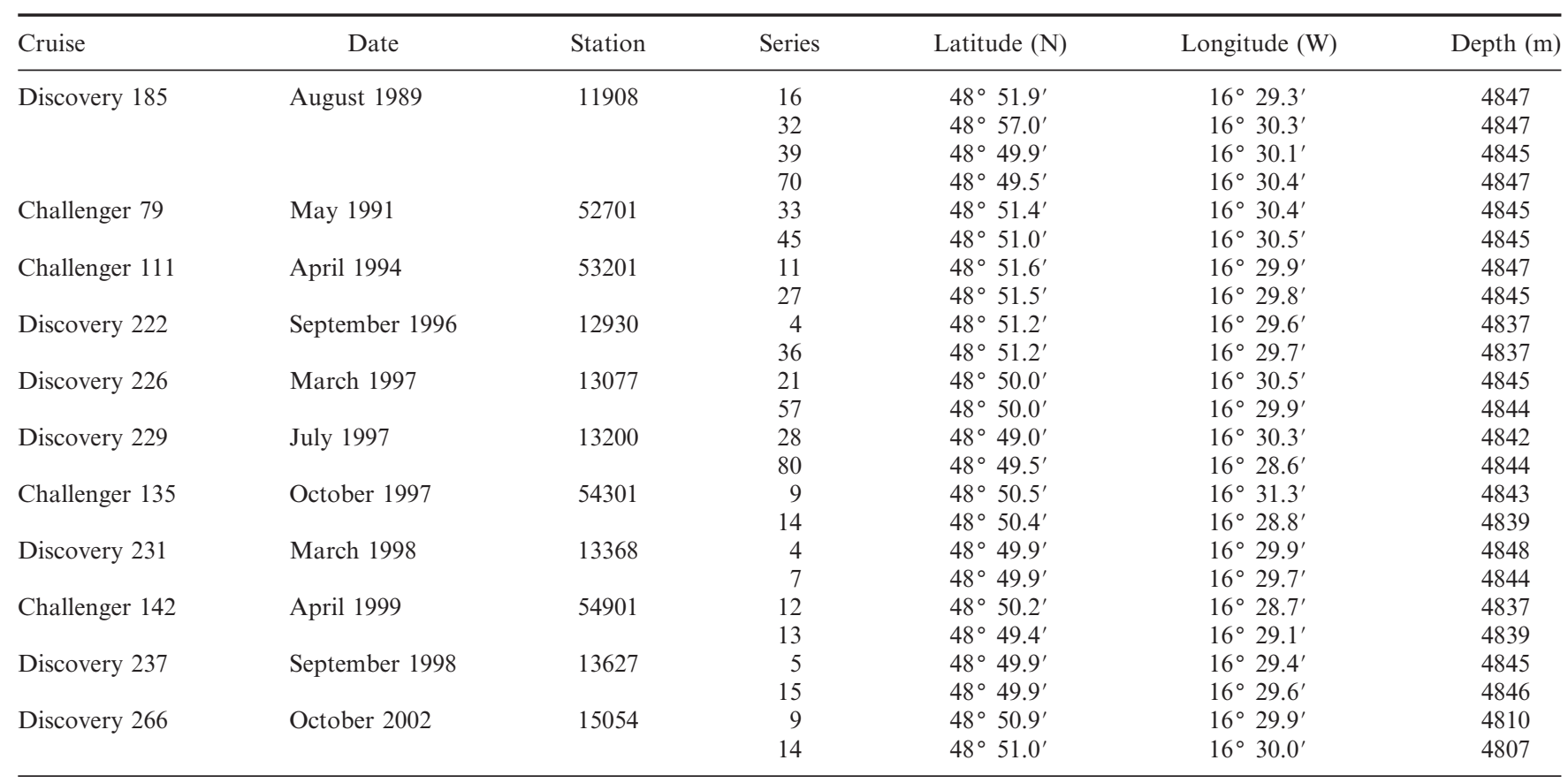

Table 1. Station details

dimensions were measured with a micrometer eyepiece (accuracy $10 \mu \mathrm{m})$ fitted to a Wild M50 dissecting microscope. Selected specimens were examined in more detail and photographed under an Olympus model BHS compound photomicroscope or in a LEO 1450VP Scanning Electron Microscope (SEM).

\section{SYSTEMATIC DESCRIPTION}

Recent suprageneric classifications are followed by placing the genus Hyperammina in the Order Astrorhizida, Superfamily Hippocrepinacea and Family Hippocrepinidae (Loeblich \& Tappan, 1987: Sen Gupta, 1999; Lee et al., 2000). Molecular genetic studies (Pawlowski et al., 2002, 2003) suggest that many of the higher taxa of morphologically simple foraminifera with organic-walled (Order Allogromiida) and agglutinated (Order Astrorhizida) tests are unnatural groupings and, therefore, this classification system is used largely for convenience.

Class Foraminifera Lee, 1990

Order Astrorhizida Brady, 1881

Superfamily Hippocrepinacea Rhumbler, 1895

Family Hippocrepinidae Rhumbler, 1895

Subfamily Hyperammininae Eimer \& Fickert, 1899

Genus Hyperammina Brady, 1878

Hyperammina micaceus sp. nov.

(Plates 1-3)

1988 Hyperammina sp. Gooday: table 2.

1995 Hyperammina sp. Gooday et al:: pl. 1, fig. D.

1996 'Hyperammina' sp. 1. Gooday: table 6, p. 1421.

Derivation of name. Refers to the plate-like particles from which the test is constructed.
Diagnosis. Test delicate but rigid, very small (length $<1 \mathrm{~mm}$ ), consisting of elongate oval proloculus merging smoothly into slender, cylindrical tube which follows a straight or gently curved course; transverse partition-like structures may interrupt the tube. Wall very thin, composed of single layer of tiny, plate-like mineral grains. Aperture terminal and simple. Cytoplasm with small inclusions and single nucleus located in the proloculus, but otherwise featureless.

Type material. The holotype (Pl. 1, fig. 1), mounted in Canada Balsam on a glass slide, is deposited in the Palaeontology Department, Natural History Museum, London, under registration number ZF5160. An additional 28 paratypes, registration number ZF5161, are mounted under a separate cover slip on the same slide.

Type locality. Discovery Station 11908, series 16, core 3 $\left(48^{\circ} 51.9^{\prime} \mathrm{N}, 16^{\circ} 29.3^{\prime} \mathrm{W}, 4847 \mathrm{~m}\right.$ water depth; collected 7 August 1989).

Description. The test is delicate but rigid. It is elongate, cylindrical and follows a straight or slightly curved course; a few larger specimens exhibit a kink-like feature. The 29 type specimens (holotype and paratypes), most of which are complete, range in length from $170 \mu \mathrm{m}$ to $920 \mu \mathrm{m}$. The test consists of a proloculus, $40-110 \mu \mathrm{m}$ (usually $60-90 \mu \mathrm{m}$ ) long and $32-45 \mu \mathrm{m}$ (usually c. $40 \mu \mathrm{m})$ wide, which occupies a variable proportion $(8-44 \%$, usually $10-20 \%$ ) of the total test length. It is usually more or less oval in shape and merges smoothly with the main tubular part of the test. Less commonly, the proloculus is more rounded and clearly delimited from the tube; occasionally, it is deformed into an asymmetrical shape. The tubular part of the test is between 


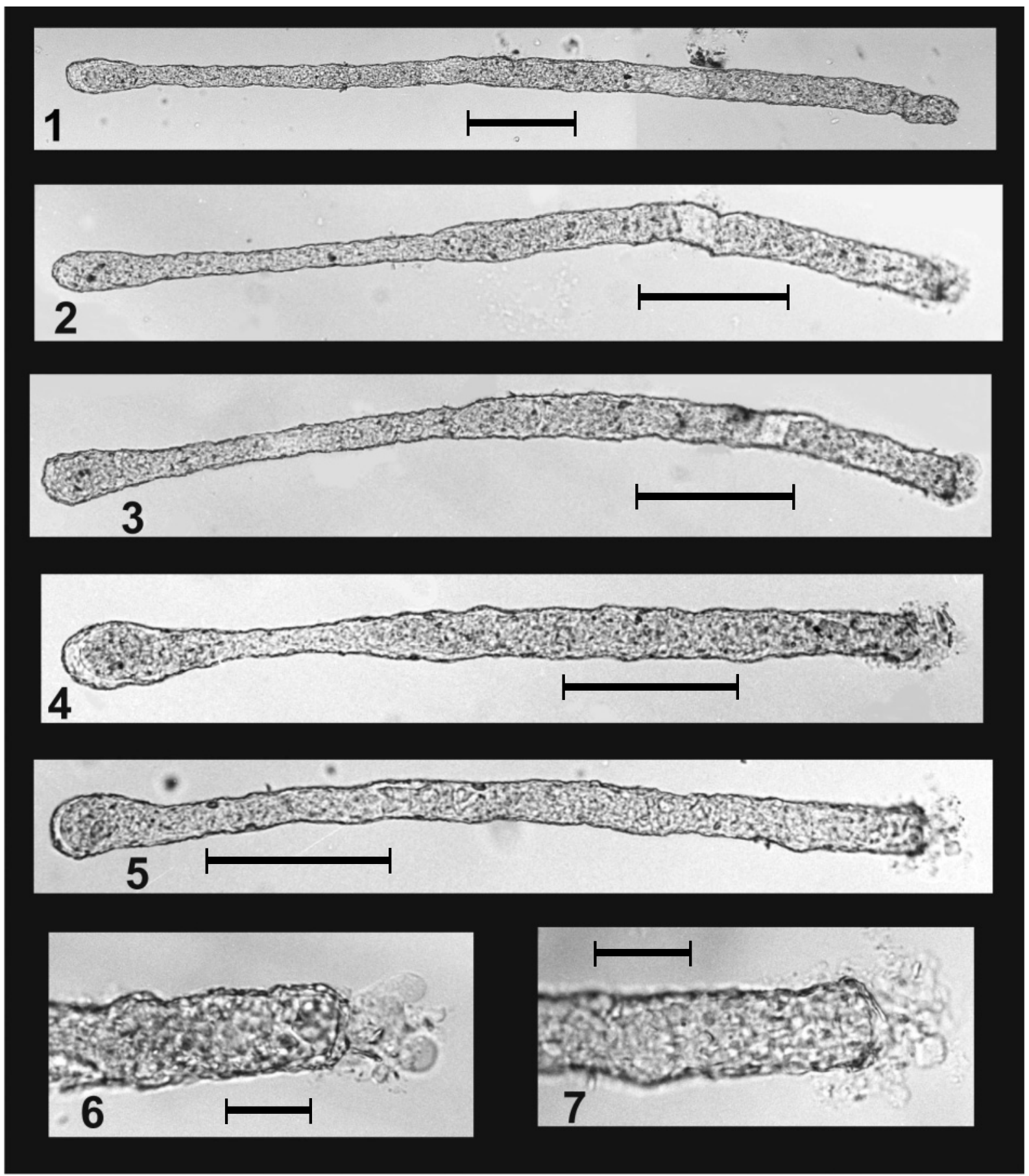

Explanation of Plate 1.

Hyperamminia micaceus sp. nov. fig. 1. Holoytype, reg. no. ZM5160. figs 2-7. Paratypes, reg no. ZM5161: 2-5, complete tests; 6, detail of apertural end with protruding cytoplasm; 7, detail of apertural end of specimen illustrated in fig. 5 showing partial closure. Figs $1-5$ taken using normal bright field illumination; figs 6-7 taken using Nomarski Interference Contrast. Scale bars: $100 \mu \mathrm{m}$ (figs 1-5); $25 \mu \mathrm{m}$ (figs 6-7).

$12 \mu \mathrm{m}$ and $32 \mu \mathrm{m}$ (usually $20-32 \mu \mathrm{m}$ ) wide. The shape is not smooth; rather, the width is slightly and irregularly variable and there is often a distinct and rather abrupt increase in width between a quarter and halfway along the length of the test (Pl. 1, figs 2-4; Pl. 2, fig. 1). Immediately before the distal end, the tube tapers towards the aperture. The aperture itself is often constricted (Pl. 1, figs 6, 7) and, occasionally, the end appears to be completely closed. A lump of protoplasm may be present immediately outside the aperture and the distal end of the tube is sometimes covered in loose, fine-grained, detrital material.

In the holotype, the tubular part of the test exhibits two transverse structures that appear to be internal partitions. A similar structure was visible in one of the 28 paratypes. The unstained cytoplasm is white or light yellow in colour and 


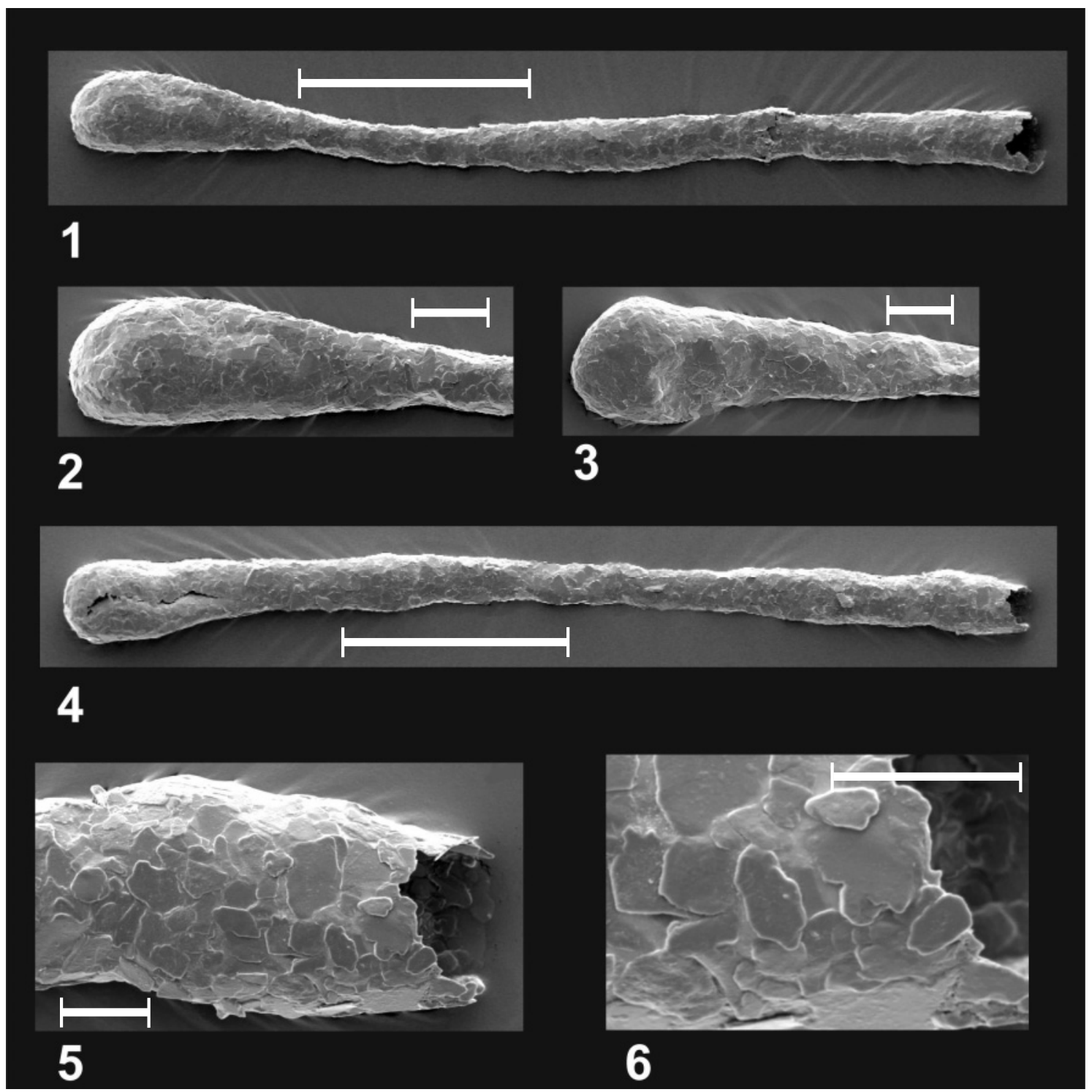

Explanation of Plate 2.

Hyperamminia micaceus sp. nov., scanning electron micrographs of unregistered specimens. figs 1, 2. Complete specimen and detail of proloculus (Station 13627\#5). fig. 3. Proloculus of second specimen (Station 13627\#5). fig. 4. complete specimen (Station 13200\#80). figs 5, 6. Details of broken end showing construction of wall (Station 13200\#80). Scale bars: $100 \mu \mathrm{m}$ (figs 1, 4); $20 \mu \mathrm{m}$ (figs 2, 3); $10 \mu \mathrm{m}$ (figs 5, 6).

contains fine small inclusions and occasional larger darkcoloured particles. A nucleus (diameter 12-20 $\mu \mathrm{m}$ ) is sometimes visible within the proloculus.

The test wall is very thin $(<1 \mu \mathrm{m})$ and consists of plate-like mineral grains, irregular in outline and $<10 \mu \mathrm{m}$, typically 3-8 $\mu \mathrm{m}$, in maximum dimension ( $\mathrm{Pl}$. 2, figs 5, 6). The plates overlap to some extent and, in places, are arranged in an imbricated pattern, although the wall is probably never more than 2-3 grains thick. Both outer and inner surfaces are slightly rough.

Variation. The description given above is based mainly on the type material. Specimens from other PAP samples are similar to the types. Eleven complete specimens range in length from $240 \mu \mathrm{m}$ to $920 \mu \mathrm{m}$. The proloculus is $20-120 \mu \mathrm{m}$ (usually
60-100 $\mu \mathrm{m}$ ) long, 20-50 $\mu \mathrm{m}$ (usually $40 \mu \mathrm{m}$ ) wide and occupies $10-38 \%$ (usually $15-30 \%$ ) of the total length of the test. A very long specimen $(L=1060 \mu \mathrm{m})$ occurred in the sample from Station 13077\#21 (Pl. 3, fig. 1). Transverse partitions are generally more common and developed more clearly than in the type material, appearing as distinct lines across the test interior (Pl. 3, figs 2, 5). Of 63 specimens examined in detail, 26 had no visible partitions, 34 had one, two had two and one had four. The partitions often occur at the point where the proloculus joins the tubular section or at about two-thirds of the length of the tube towards the distal end. Occasionally, single coarse sand grains or diatoms are scattered on the exterior of the test.

Specimen counts are based on tests that include a proloculus, but broken tests without a proloculus are often common (Table 2). These tubular fragments vary in width but, typically, 


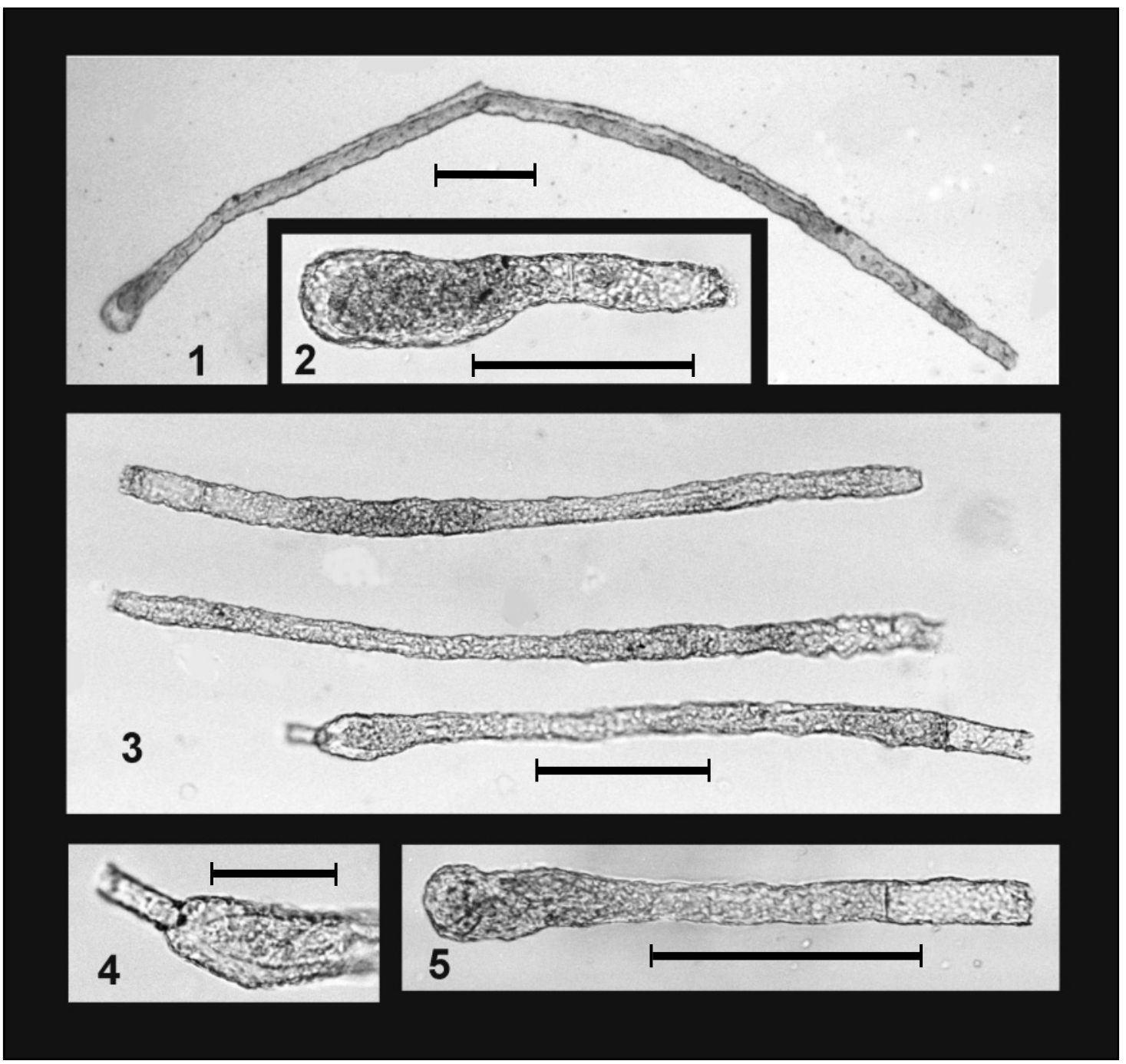

Explanation of Plate 3.

Hyperamminia micaceus sp. nov., unregistered specimens from Stn 13077\#21, mounted in glycerol. fig. 1. Unusually long individual. fig. 2. Short, complete individual with transverse, partition-like feature (arrowed). fig. 3. Three fragmentary specimens lacking proloculus. fig. 4. Tubular extension at end of fragmentary specimen. fig. 5. Specimen with partition-like structure (arrowed). Scale bars: $100 \mu \mathrm{m}$ (figs 1-3, 5); 25 $\mu \mathrm{m}$ (fig. 4).

are rather slender (P1. 3, fig. 3). The end of one fragment from Station $13077 \# 21$ was constricted and gave rise to a short, stolon-like extension (P1. 3, fig. 4), possibly the result of an interruption in growth.

Remarks. This tiny species is much smaller $(<1 \mathrm{~mm})$ than most other species of Hyperammina (e.g. see Brady, 1884; Cushman, 1918; Höglund, 1947; Zheng \& Fu, 2001). The very thin test wall composed of a single layer of plate-like mineral grains is also distinctive. Members of this genus usually have a wall consisting of several layers of particles, usually sand grains or sponge spicules (Hofker, 1972). The most similar species is probably H. tenuissima Heron-Allen \& Earland, 1922, which reaches a length of $1.5 \mathrm{~mm}$, according to the original description of the type material from $1740 \mathrm{~m}$ depth in the Ross Sea. The specimen of $H$. tenuissima illustrated by Zheng \& Fu (2001, pl. IX, fig. 3 therein) measures just over $0.5 \mathrm{~mm}$ and closely resembles
H. micaceus in general shape as well as in size. However, Heron-Allen \& Earland's (1922) description suggests that the proloculus of $H$. tenuissima is more bulbous than in the new species, while the test wall is brown in colour and has a smooth, polished surface. Hyperamminia magnilocula Zheng \& Fu, 2001, from $1010 \mathrm{~m}$ depth in the South China Sea, is another small species (length $1.63 \mathrm{~mm}$ ), similar in shape to H. micaceus (Zheng \& Fu, 2001, pl. IX, fig. 4 therein) but with a test composed of loosely agglutinated, very fine sand grains rather than plate-like particles. Lacroix (1928) described Hyperammina dubia, a species a few millimetres in length, from $30-40 \mathrm{~m}$ water depth off Monaco. In this case, the test tapers to a point at the proximal end and is composed of sand grains.

Samples from the PAP and other deep-sea sites often yield a number of other very small (length $<1 \mathrm{~mm}$ ), undescribed, Hyperammina-like species. Such forms have also been observed in coastal waters around Svalbard (Gooday et al., unpublished). 


\begin{tabular}{|c|c|c|c|c|c|}
\hline Station & Date & \multicolumn{2}{|c|}{$n$} & $\%$ total & Comments \\
\hline 11908\#16: & August 1989 & & & & \\
\hline core 3 & & 52 & 15 & 18.2 & A few phytodetrital lumps \\
\hline core $7^{\mathrm{b}}$ & & 25 & ND & 1.60 & $1-5 \mathrm{~mm}$ layer of phytodetritus \\
\hline core $8^{\mathrm{b}}$ & & 22 & ND & 3.01 & Patchy layer of phytodetritus \\
\hline $11908 \# 32$ & August 1989 & 13 & ND & 2.31 & c. 25 phytodetrital lumps \\
\hline $52701 \# 33^{\mathrm{a}}$ & May 1991 & 16 & ND & 2.47 & No visible phytodetritus \\
\hline $52701 \# 45$ & May 1991 & 15 & ND & 1.87 & $2-5 \mathrm{~mm}$ layer of phytodetritus \\
\hline $53201 \# 27^{\mathrm{a}}$ & April 1994 & 0 & 0 & 0 & No visible phytodetritus \\
\hline $53201 \# 11$ & April 1994 & 0 & 0 & 0 & No visible phytodetritus \\
\hline $12930 \# 4$ & September 1996 & 8 & 5 & 2.21 & Large worm cast \\
\hline $12930 \# 36$ & September 1996 & 13 & 36 & 1.68 & Single large phytodetrital lump \\
\hline $54301 \# 14^{\mathrm{a}}$ & October 1997 & 4 & ND & 0.31 & ND \\
\hline $13368 \# 4^{\mathrm{a}}$ & March 1998 & 12 & ND & 0.88 & No visible phytodetritus \\
\hline $13368 \# 7^{\mathrm{a}}$ & March 1998 & 4 & ND & 0.50 & No visible phytodetritus \\
\hline $13627 \# 5^{\mathrm{a}}$ & September 1998 & 36 & ND & 2.64 & No visible phytodetritus \\
\hline $13627 \# 15^{\mathrm{a}}$ & September 1998 & 16 & ND & 0.74 & No visible phytodetritus \\
\hline $54901 \# 12^{\mathrm{a}}$ & April 1999 & 4 & ND & 0.26 & ND \\
\hline $54901 \# 13^{\mathrm{a}}$ & April 1999 & 8 & ND & 0.56 & ND \\
\hline $15054 \# 9^{\mathrm{a}}$ & October 2002 & 4 & ND & 0.31 & ND \\
\hline $15054 \# 14^{\mathrm{a}}$ & October 2002 & 0 & ND & 0 & ND \\
\hline
\end{tabular}

Numbers of specimens with a proloculus and fragments without a proloculus are given separately. The percentages in column 5 are based on specimens with a proloculus only. ND, no data.

a $1 / 4$ sub-samples

$\mathrm{b}_{\text {syringe sub-samples }}$

Table 2. Absolute and relative abundances of Hyperammina micaceous sp. nov. in multicorer samples from the Porcupine Seabight.

Unlike H. micaceous, however, they have soft, flexible, very finely agglutinated walls and tubular sections that increase smoothly in width. These tiny foraminiferans are probably a widespread but overlooked component of benthic assemblages in many muddy marine sediments.

Species of Hyperammina raise interesting questions regarding the distinction between the single- and multi-chambered organization of foraminiferal tests. Molecular evidence suggests that some species branch within the radiation of monothalamous (single-chambered) foraminifera (Pawlowski et al., 2003) whereas morphology-based diagnoses (e.g. Loeblich \& Tappan, 1987; Sen Gupta, 1999, table 2.1 therein) regard Hyperammina as two-chambered, the proloculus being the first chamber and the tubular extension the second. In fact, the boundary between these two test components is often not clear. They tend to merge into each other and neither resembles the chambers of typical multi-chambered taxa which are separated by walls perforated by foramina. The transverse partitions visible in some specimens of $H$. micaceus do subdivide the tube into two or more compartments, but these structures are not always present and have no expression on the test exterior. Similarly, the variations in width along the length of the tube are too slight and irregular to be regarded as chambers. On balance, Hyperammina is best considered as a tubular monothalamous taxon in which the closed proximal end of the tube is expanded to form a bulb-like structure. In many respects, it resembles the genus
Bathysiphon, some species of which also exhibit internal transverse partitions and irregular fluctuations in width (Gooday et al., 1992).

\section{ABUNDANCE AND MICROHABITAT OCCUPANCY}

Hyperammina micaceus appears to be a fairly widespread component of abyssal assemblages in the northeast Atlantic. In addition to the type locality on the PAP, it occurs at the BIOTRANS Site $\left(47^{\circ} 00^{\prime}-47^{\circ} 30^{\prime} \mathrm{N}, 19^{\circ} 00^{\prime}-20^{\circ} 00^{\prime} \mathrm{W}, 4450 \mathrm{~m}\right)$ (Gooday, 1988, as Hyperammina sp.) and at a shallower water depth $(2880 \mathrm{~m})$ in the Iceland Basin (Gooday et al., 1995, as Hyperammina $\mathrm{sp}$.).

The new species occurred in all except three of the 24 examined multicore samples collected at the PAP site between 1989 and 2002 (Table 2). It usually constituted $<4 \%$ of the live assemblage $(0-1 \mathrm{~cm}$ layer, $>63 \mu \mathrm{m}$ size fraction), except in one sample (11908\#16, core 3) where it made up 18.2\%. Hyperammina micaceus tended to be more common in the summer months, following the spring bloom, than later in the year or prior to the spring bloom. Samples collected in May (Stn 52701), July (Stn 13200), August (Stn 11908) and September (Stns 12930, 13368) yielded between 13 and 52 specimens (mean 21.8, SD $11.18, n=14$ ), representing between $0.74 \%$ and $4.0 \%$, in one case $18.2 \%$ (Stn 11908\#16, core 3), of the live foraminiferal assemblage. Samples collected in October (Stns 54301, 15054), March (13077) and April (53201, 54901) yielded between 0 and 
A. J. Gooday \& M. G. Malzone

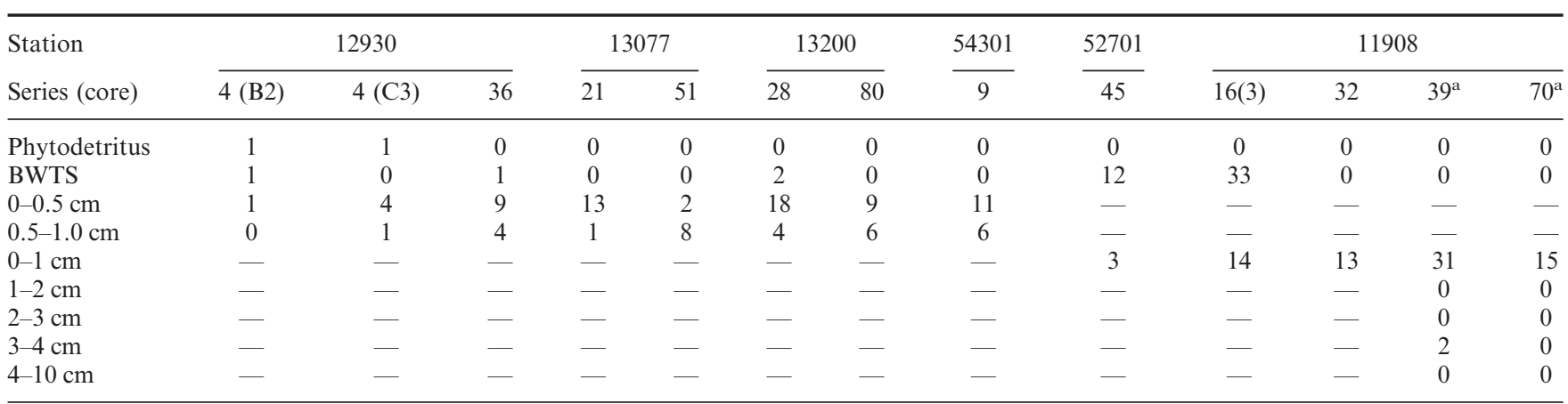

Note that at Stns 12930, 13077, 13200 and 54301, the top $1 \mathrm{~cm}$ of the cores was split into two layers, while at Stns 52701 and 11908 it was not. BWTS, bottom water + topmost sediment.

${ }^{\text {a }}$ Cores from $11908 \# 39$ and 70 were analysed in $1 \mathrm{~cm}$ layers down to $10 \mathrm{~cm}$ depth.

Table 3. Occurrence of specimens of Hyperammina micaceus in surficial sediment layers of samples from the Porcupine Abyssal Plain

18 species (mean 7.0, SD 5.71, $n=10$ ), representing $0-1.7 \%$ of the total assemblage. However, there was no clear relationship between the abundance of $H$. micaceus and the presence of phytodetrital deposits. For example, at Station 11908\#16, the species was more common in core 3 , which yielded only a few phytodetrital aggregates, than in cores 7 and 8 where phytodetritus formed a distinct surface layer.

Hyperammina micaceus mainly occurs in surficial sediment layers. In samples from Stns 12930, 13077, 13200 and 54301, in which the top $1 \mathrm{~cm}$ layer was divided into half-centimetre intervals, specimens were always more abundant in the $0-0.5 \mathrm{~cm}$ layer than in the $0.5-1.0 \mathrm{~cm}$ layer, and few occurred in the sediment pipetted from the core surface and the overlying phytodetritus layer (where present) (Table 3). Samples from Stns 52701 and 11908 were divided into $1 \mathrm{~cm}$ horizons (Table 3). In two of these cores $(52701 \# 45$ and $11908 \# 16)$, the majority of specimens were concentrated in the sediment immediately beneath the phytodetrital layer. Two other cores (11908\#39 and 70) were sorted for live foraminifera to $10 \mathrm{~cm}$ depth; in one case, two live specimens of the new species were recovered from the 3-4 cm layer.

\section{ACKNOWLEDGEMENTS}

The authors are grateful to Alan Hughes for the SEM photographs, to Mrs Kate Davis for help with the plates and to Drs Sam Bowser, John Gregory and Chris Smart for their constructive comments on the manuscript.

\section{Manuscript received 29 March 2004 Manuscript accepted 26 July 2004}

\section{REFERENCES}

Barnett, P.R.O., Watson, W. \& Connelly, D. 1984. A multiple corer for taking virtually undisturbed samples from shelf, bathyal and abyssal sediment. Oceanologica Acta, 7: 399-408.

Bett, B.J., Malzone, M.G., Narayanaswamy, B.E. \& Wigham, B.D. 2001. Temporal variability in phytodetritus and megabenthic activity at the seabed in the deep northeast Atlantic. Progress in Oceanography, 50: 349-368.

Billett, D.S.M., Lampitt, R.S., Rice, A.L. \& Mantoura, R.F.C. 1983. Seasonal sedimentation of phytodetritus to the deep-sea benthos. Nature, 302: 520-522.

Billett, D.S.M., Bett, B.J., Thurston, M.H., Galeron, J., Sibuet, M. \& Wolff, G.A. 2001. Long-term change in the megabenthos of the
Porcupine Abyssal Plain (NE Atlantic). Progress in Oceanography, 50: 325-348.

Brady, H.B. 1878. On the reticularian and radiolarian Rhizopoda (Foraminifera and Polycystina) of the North Polar Expedition of 1875-76. Annals and Magazine of Natural History, ser. 5, 1: 425-440.

Brady, H.B. 1884. Report on the Foraminifera dredged by H.M.S Challenger during the years 1873-1876. Report of the Scientific Results of the Voyage of H.M.S. Challenger, 1873-1876, Zoology, 9: $1-814$.

Cushman, J.A. 1918. The foraminifera of the Atlantic Ocean. Pt. 1. Astrorhizidae. United States National Museum, Bulletin, 104 (1): $1-111$.

Gooday, A.J. 1988. A response by benthic Foraminifera to the deposition of phytodetritus in the deep sea. Nature, 332: 70-73.

Gooday, A.J. 1990. Recent deep-sea agglutinated Foraminifera: a brief review. In: Hemleben, C., Kaminski, M.A., Kuhnt, W. \& Scott, D.B. (Eds), Paleoecology, biostratigraphy, paleoceanography and taxonomy of agglutinated foraminifera. Kluwer Academic Publishers, Dordrecht, 271-304.

Gooday, A.J. 1996. Epifaunal and shallow infaunal foraminiferal communities at three abyssal NE Atlantic sites subject to differing phytodetritus input regimes. Deep-Sea Research I, 43: 1395-1421.

Gooday, A.J. 2002. Biological responses to seasonally varying fluxes of organic matter to the ocean floor: a review. Journal of Oceanography, 58: $305-332$.

Gooday, A.J. \& Rathburn, A.E. 1999. Temporal variability in living deep-sea foraminifera: a review. Earth Sciences Reviews, 46: $187-212$.

Gooday, A.J., Levin, L.A., Thomas, C.L. \& Hecker, B. 1992. The taxonomy, distribution and ecology of Bathysiphon filiformis and B. major (Protista, Foraminiferida) on the continental slope off North Carolina. Journal of Foraminiferal Research, 22: 129-146.

Gooday, A.J., Carstens, M. \& Thiel, H. 1995. Micro- and nanoforaminifera from abyssal northeast Atlantic sediments: a preliminary report. Internationale Revue gesampten Hydrobiologie, 80: 361-383.

Gooday, A.J., Bett, B.J., Shires, R. \& Lambshead, P.J.D. 1998. Deepsea benthic foraminiferal species diversity in the NE Atlantic and NW Arabian sea: a synthesis. Deep-Sea Research II, 45: 165-201.

Heron-Allen, E. \& Earland, A. 1922. Protozoa; Part II - Foraminifera. Natural History Report British Antarctic 'Terra Nova' Expedition, London (Zoology), 6: 25-268.

Hofker, J. 1972. Primitive Agglutinated Foraminifera. E.J. Brill, Leiden, $95 \mathrm{pp}$.

Höglund, H. 1947. Foraminifera in the Gullmar Fjord and the Skagerak. Zoologiska Bidrag frå Uppsala, 26: 1-328.

Jensen, P. 1982. A new meiofauna sample splitter. Annales Zoologici Fennici, 19: 233-236.

Lacroix, E. 1928. Les Astrorhizides du littoral Mediterranean entre Saint-Raphäel et Monaco. Bulletin de l'Institut Océanographique Monaco, No., 545: 1-22. 
Lee, J.J., Leedale, G.F. \& Bradbury, P. 2000. An Illustrated guide to the Protozoa 2nd Edition, II. Society of Protozoologist, Lawrence, Kansas, 690-1432.

Levin, L.A. \& Gooday, A.J. 2003. The deep Atlantic Ocean. In: Tyler, P.A. (Ed.), The Deep Seafloor. Ecosystems of the World. Elsevier, Amsterdam, 111-178.

Loeblich, A.R. \& Tappan, H. 1987. Foraminiferal Genera and their Classification. Van Nostrand Reinhold, New York, 970pp.

Pawlowski, J., Holzmann, M., Berney, C., Fahrni, J., Cedhagen, T. \& Bowser, S.S. 2002. Phylogeny of allogromiid Foraminifera inferred from SSU rRNA gene sequences. Journal of Foraminiferal Research, 32: 334-343.

Pawlowski, J., Holzmann, M. \& Berney, C. et al. 2003. The evolution of early Foraminifera. Proceedings of the National Academy of Sciences, 100: 11494-11498.

Rice, A.L., Billett, D.S.M., Fry, J., John, A.W.G., Lampitt, R.S. Mantoura, R.F.C. \& Morris, R.J. 1986. Seasonal deposition of phytodetritus to the deep-sea floor. Proceedings of the Royal Society of Edinburgh, 88B: 265-279.
Rice, A.L., Thurston, M.H. \& Bett, B.J. 1994. The IOSDL DEEPSEAS programme: photographic evidence for the presence and absence of a seasonal input of phytodetritus at contrasting abyssal sites in the north-eastern Atlantic Ocean. Deep-Sea Research I, 41: 1305-1320.

Sen Gupta, B.K. 1999. Systematics of modern Foraminifera. In: Sen Gupta, B.K. (Ed.), Modern Foraminifera. Kluwer Academic Publishers, Norwell, MA, 403-422.

Snider, L.J., Burnett, B.R. \& Hessler, R.R. 1984. The composition and distribution of meiofauna and nanobiota in a central North Pacific deep-sea area. Deep-Sea Research, 31: 1225-1249.

Thurston, M.H., Bett, B.J., Rice, A.L. \& Jackson, P.A.B. 1994. Variations in the invertebrate abyssal megafauna in the North Atlantic Ocean. Deep-Sea Research, 41: 1321-1348.

Zheng, S. \& Fu, Z. 2001. Fauna Sinica. Phylum Granuloreticulosa, Class Foraminiferea, Agglutinated Foraminifera. Science Press, Beijing, 788pp. 